\title{
Stabilization of carbon in mineral soils from mangroves of the Sinú river delta, Colombia
}

\author{
Heidi Völkel · Jhoanata M. Bolivar · Carlos A. Sierra
}

Received: 6 July 2017 / Accepted: 3 August 2018/Published online: 7 August 2018

(C) The Author(s) 2018

\begin{abstract}
Mangrove forests of the Sinú river delta in Cispatá bay, Colombia, show large differences in soil carbon storage between fringe (oceanic) and basin (estuarine) mangroves. We were interested in testing whether these differences in soil carbon are associated with sediment transport processes or whether most of the carbon is produced in situ within the mangrove system. Given past sedimentation dynamics of the Sinú river, we hypothesized that a large portion of soil carbon in basin mangroves is due to sedimentation. We determined total organic carbon content (TOC) as $660.93 \pm 259.18 \mathrm{MgC} \mathrm{ha}^{-1}$ for basin soils up to a sampling depth of $1 \mathrm{~m}$, and as $259 \pm 42.61 \mathrm{MgC} \mathrm{ha}^{-1}$ for fringe soils up to $80 \mathrm{~cm}$ depth (maximum soil depth for fringe soils). Using analyses of mineralogy (Aland Fe-oxides, clay minerals) as well as isotopic analyses of carbon $\left(\delta^{13} \mathrm{C}\right)$, the origin of the sediments and their carbon was determined. We found that basin soils in Cispatá bay show similar mineralogical composition than those of fluvial sediments, but the carbon concentration of river sediments was close to zero. Given the large capacity of the $\mathrm{Fe}$ and $\mathrm{Al}$ oxides in clay minerals to store dissolved carbon, and that the
\end{abstract}

H. Völkel · C. A. Sierra ( $\square)$

Max Planck Institute for Biogeochemistry, Hans-Knöll

Str. 10, 07745 Jena, Germany

e-mail: csierra@bgc-jena.mpg.de

J. M. Bolivar

Research Center on Ecosystems and Global Change

Carbono \& Bosques, Medellín, Colombia isotopic composition of the carbon is mostly of plant origin, we concluded contrary to our initial hypothesis that the carbon stored in basin mangrove soils are produced in situ. The deposited fluvial sediments do play an important role for carbon storage, but mostly in providing binding surfaces for the stabilization of organic carbon.

Keywords Soil organic carbon - Stable isotopes · Iron and aluminum oxides - Soil mineralogy · Estuarine ecosystems

\section{Introduction}

Although mangroves are ecosystems with some of the largest levels of carbon storage on earth (Donato et al. 2011; Alongi 2012), there are large variations on the amount of $\mathrm{C}$ stored in various systems, particularly soils. For instance, mangrove ecosystems dominated by Rhizophora spp. in Peninsular Malaysia store between 479 and $2205 \mathrm{Mg} \mathrm{C}^{-1}$ in the belowground and soil pool (Alongi 2012), and similar levels of variability have been observed at other sites (Jardine and Siikamäki 2014). It is unclear however, what are the main determinants of observed differences in soil $\mathrm{C}$ storage across diverse mangrove systems. It is possible that differences in soil carbon storage are due to differences in the level of productivity of different 
mangrove systems, or due to other external sources such as sediment transport.

This large degree of spatial variability in soil carbon storage is also well expressed in the mangrove forests of Cispatá bay, Colombia. These mangroves consist of two main forest types: basin and fringe systems, which show large differences in terms of soil carbon stocks between them. A previous study (Bolívar 2015) showed that for basin mangroves the total organic carbon storage (TOC) is around $740 \pm 40$ $\mathrm{Mg} \mathrm{C} \mathrm{ha}{ }^{-1}$, while for the fringe mangroves this value is only $95 \pm 9 \mathrm{MgC} \mathrm{ha}^{-1}$. These numbers, particularly for the basin mangroves, are in the upper range of values observed for other systems (Donato et al. 2011; Alongi 2012; Jardine and Siikamäki 2014).

It is unknown whether the high levels of soil carbon in Cispatá bay are due to the intrinsically high levels of productivity of these systems or whether this soil carbon has an external source such as transport of fluvial or marine sediments. Given that mangrove productivity is high and decomposition in water saturated soils is slow, carbon stored in these systems may not have any external origin (Lacerda et al. 1995). However, it is also possible that sediments in the delta region may have been deposited by the Sinú river given that before 1938 it discharged in the current mangrove area (Serrano 2004), in which case the carbon stored in these sediments may have its origins in soils from the northern Andean mountains. Alternatively, the carbon in these sediments may have been transported by marine tides over the Caribbean.

Different techniques have been used in the past to determine different sources of organic carbon in water saturated ecosystems. For instance, the $\delta^{13} \mathrm{C}$ isotope has been used to explore different sources of carbon by source partitioning analyses (Bouillon et al. 2008; Spohn and Giani 2012; Spohn et al. 2013). Also, measurements of the mineralogical composition of the sediments can also give some clues on whether the minerals present in an area are from terrestrial or marine origin.

Here, our main objective was to determine the origin of the relatively high carbon levels in these soils using elemental and isotopic analyses of carbon as well as analyses of the soils' mineralogy in concert with Al- and $\mathrm{Fe}$-oxide measurements. In particular, we expect that: (1) the isotopic composition $\left(\delta^{13} \mathrm{C}\right)$ of soil carbon provides information on whether riverine sediments are a main source of $\mathrm{C}$ in Cisipatá bay,
Colombia; and (2) the mineralogical composition of the sediments provides additional information on the origin of the soil carbon and the potential that it is mostly stabilized on the surface of Fe- and Al-oxides. Our main hypothesis is that soils in the basin mangroves are composed mainly by sediments transported by the Sinú river and deposited in the delta region, therefore explaining the relatively large values of TOC stored in these soils.

\section{Materials and methods}

\section{Study site}

The study site is located on the northwestern Caribbean coast in Colombia $\left(9^{\circ} 23^{\prime} \mathrm{N} 75^{\circ} 52^{\prime} \mathrm{W}\right)$, which is part of the southern extreme of Morrosquillo gulf and it is locally known as Cispatá bay (Fig. 1). The coastal zone is characterized by the Sinú river delta and a complex estuarine lagoon system that covers approximately 5,098 ha. Extensive wetlands and mangroves dominate this area. The Sinú river has its origin in the northern part of the western Andean mountains, and between 1938 and 1945 changed its course creating a new delta (Serrano 2004). The current estuarine mangrove system was established in the previous river delta. Fringe forests are dominated by Rhizophora mangle, basin forests are dominated by Avicennia germinans. Laguncularia racemosa occurs in both forest types.

\section{Field sampling}

Our sampling focused on a set of existing plots previously established to determine the carbon sequestration potential of the mangroves of Cispatá bay (Bolívar 2015). We sampled 10 plots of $500 \mathrm{~m}^{2}$ up to 1 $\mathrm{m}$ in depth from March 12 to 13, 2016, using a soil corer of $7 \mathrm{~cm}$ in diameter (Eijkelkamp bi-partite gouge auger 04.03, Giesbeek, The Netherlands). We selected five randomly chosen points within each plot to extract soil cores at five fringe mangrove sites (plots P21, R1, R4, R5, R6) and at five basin mangrove sites (plots $\mathrm{P} 16, \mathrm{C} 1, \mathrm{C} 2, \mathrm{C} 3, \mathrm{C} 4)$. In addition to the ten plots sampled across the mangrove area, three nearby sand cores at Nisperal coast were collected, and also three riverbed cores of the Sinú river near the city of Montería, which is located $70 \mathrm{~km}$ south from Cispatá 
Fig. 1 Sampling plots in Cispatá Bay and Montería, Colombia, ArcGIS-source: http://www.diva-gis.org/ gdata; accessed on June 07, 2016; fringe plots: P21, R1, R4, R5, R6; basin plots: P16, $\mathrm{C} 1, \mathrm{C} 2, \mathrm{C} 3, \mathrm{C} 4$; end-members: Sand Nisperal, Sinú riverbed

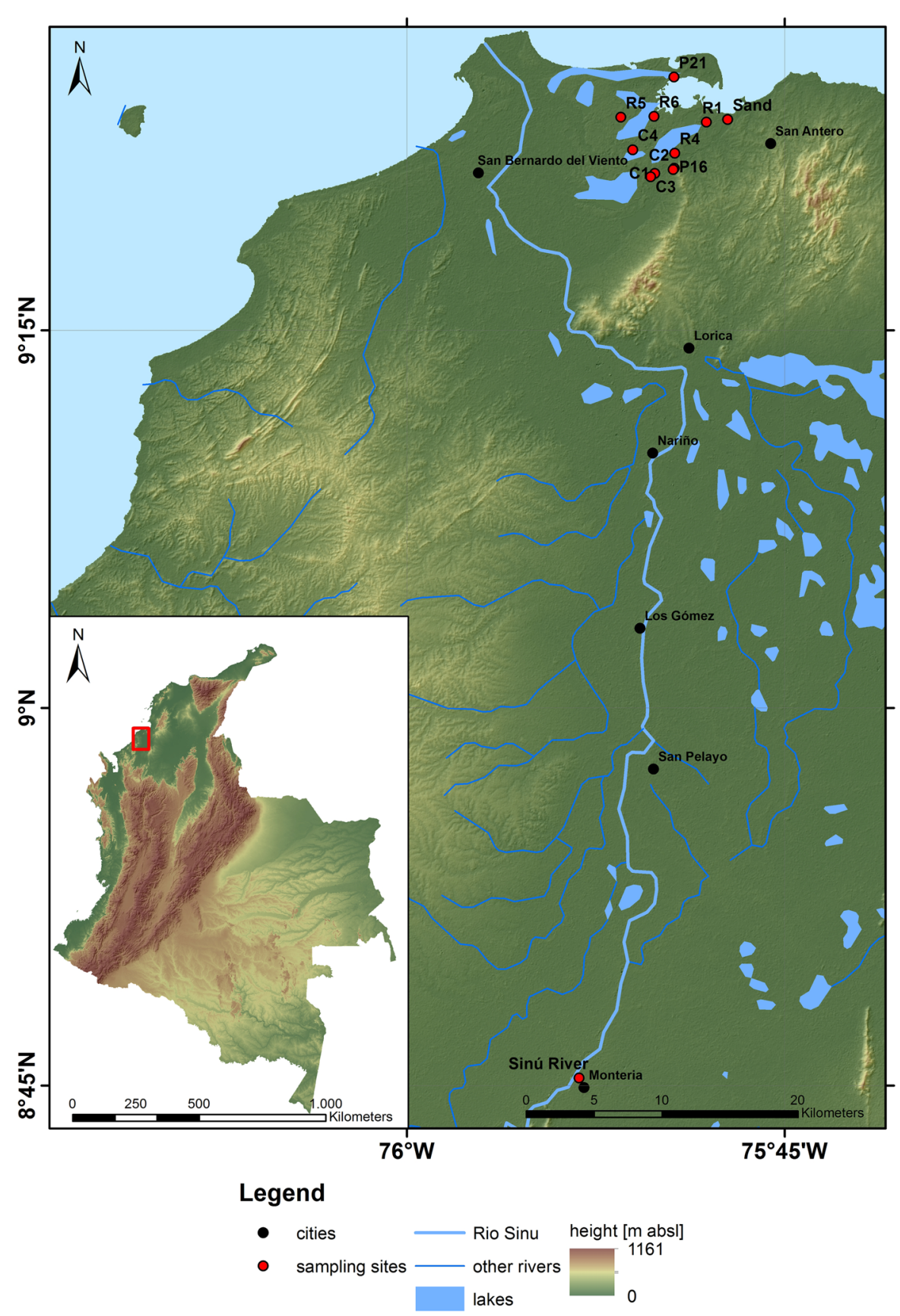

bay (Fig. 1). These river and beach sediment samples were used as end-members in our isotopic analysis. Generally, cores without layer changes were divided into sections every $20 \mathrm{~cm}$ to explore differences in carbon concentration with depth. We divided conspicuous layer changes at the boundary, except for the sand and river sediment samples that were analyzed as one single sample for mineralogical and elemental composition.

Additionally, we selected one fringe and one basin mangrove plot (P21 and C4) to measure bulk density. At each site, a soil pit was dug three meters away from one of the corners of the plot and samples were collected using sampling rings with a volume of 98.52 $\mathrm{cm}^{3}$. We collected four depth levels at plot P21 (0-20, 
20-40, 40-60, 60-80 cm) and five depth levels (+ 80-100 cm) at plot C4. Sampling for bulk density was replicated three times for each depth level. In total, we obtained 60 soil samples out of the mangrove area, 6 end-member samples, and 27 samples for bulk density measurements.

\section{Laboratory analyses}

After collection, samples were oven-dried at $70{ }^{\circ} \mathrm{C}$ for 5 days. Samples for bulk density measurements were oven dried at $105^{\circ} \mathrm{C}$. We calculated soil bulk density as dry mass divided by fresh volume $\left(\mathrm{V}=98.52 \mathrm{~cm}^{3}\right)$. Each sample was ground for $3 \mathrm{~min}$ at a frequency of 25 $\mathrm{Hz}$ using a ball mill (Retsch MM 400, Haan, Germany).

We conducted elemental analyses of percent carbon (\%TC) and nitrogen (\% TN) in all samples by dry combustion (Vario Max, Elementar Analysensysteme $\mathrm{GmbH}$, Hanau, Germany). Organic carbon was later removed by ignition at $450{ }^{\circ} \mathrm{C}$ for $16 \mathrm{~h}$, and inorganic carbon (\% IC) was then determined using the same elemental analyzer. Organic carbon concentrations were estimated by subtracting \%IC from \% TC. TOC contents $\left(\mathrm{Mg} \mathrm{ha}^{-1}\right)$ were calculated using the obtained bulk densities for basin and fringe mangrove soils multiplied by each plot depth interval $(\mathrm{cm})$ and \%OC.

We used $\delta^{13} \mathrm{C}$ values of the sampled material and compared them with the ${ }^{13} \mathrm{C} /{ }^{12} \mathrm{C}$ ratio of the two chosen end-members as indicators for the origin of the carbon (Fry 2006). We measured ${ }^{13} \mathrm{C}$ of all samples using a Finnigan MAT IRMS coupled with an EA 1100 elemental analyzer. Ali-j3 (Acetanilide-Jena3) and Caf-j3 (a caffeine sample from a 'Traube synthesis' in large supply) were chosen as internal working standards (Werner and Brand 2001). All elemental and isotopic analyses were conducted at the Max Planck Institute for Biogeochemistry in Jena, Germany.

We conducted X-ray diffraction (XRD) measurements for qualitative and quantitative phase analyses (Spieß et al. 2009) on 12 representative samples including 4 end-member samples, and 4 samples of basin and fringe mangroves each. Samples were measured $20 \mathrm{~min}$ each, from 5 to $60^{\circ} 2 \theta$. We determined each mineral phase using the powder diffraction file (PDF) data. We also conducted a Rietveld refinement analysis using the Topas software (Bruker Corporation). To define the type of clays included in the samples, we further measured each sample before extracting clay fraction from 3 to $70^{\circ} 2 \theta$ using ceramic panels. XRD analyses were conducted at the laboratory for Mineralogy and Geochemistry of the Friedrich-Schiller University in Jena, Germany.

We determined iron and aluminum in acid-ammonium-oxalate extracts $(\mathrm{pH} 3.0)$ and in sodium-citratedithionite extracts (pH 7.3) (Schwertmann 1964; Holmgren 1967). We selected 46 samples and 2 standard soils for these measurements. While sodium dithionite was used to extract both crystalline and amorphous oxides, the oxalate method extracted only amorphous oxides. The actual measurement of crystalline and amorphous iron and aluminium oxides was performed using an atomic emission spectrometer with inductive coupled plasma (ICP-AES, Optima 3300DV, PerkinElmer, Norwalk, USA). These analyses were performed at the SpecLab of the Max Planck Institute for Biogeochemistry.

\section{Data analysis}

We performed statistical tests to determine differences in organic carbon concentrations, total organic carbon, $\delta^{13} \mathrm{C}$, and $\mathrm{Fe}$ - and Al-oxides, among the fringe and basin mangroves. After an initial test for normality (Shapiro-Wilk test), we found little evidence to support the normality assumption required in common tools such as ANOVA or t-tests. We therefore, performed the non-parametric Mann-Whitney $U$ test, which is equivalent to the two-sample Wilcoxon test (Hollander et al. 2015) under the null hypothesis that the samples from the fringe and basin mangroves differ by a shift location $\mu=0$, and the alternative hypothesis that they are different by some other shift location. In other words, the test helps to determine whether the samples from the two different mangrove types belong to the same statistical distribution as stated in the null hypothesis. Data and code to reproduce all results presented here can be obtained from the following repository https://github.com/ crlsierra/mangroveCstabilization.git.

\section{Results}

We found important differences between fringe and basin mangroves in terms of \%OC ( $p$-value $<0.001$; two-sample Wilcoxon $W$-test, $W=62)$ and \% $\mathrm{TN}(p$ value $<0.001, W=102$ ) (Fig. 2). In general, \%OC and 

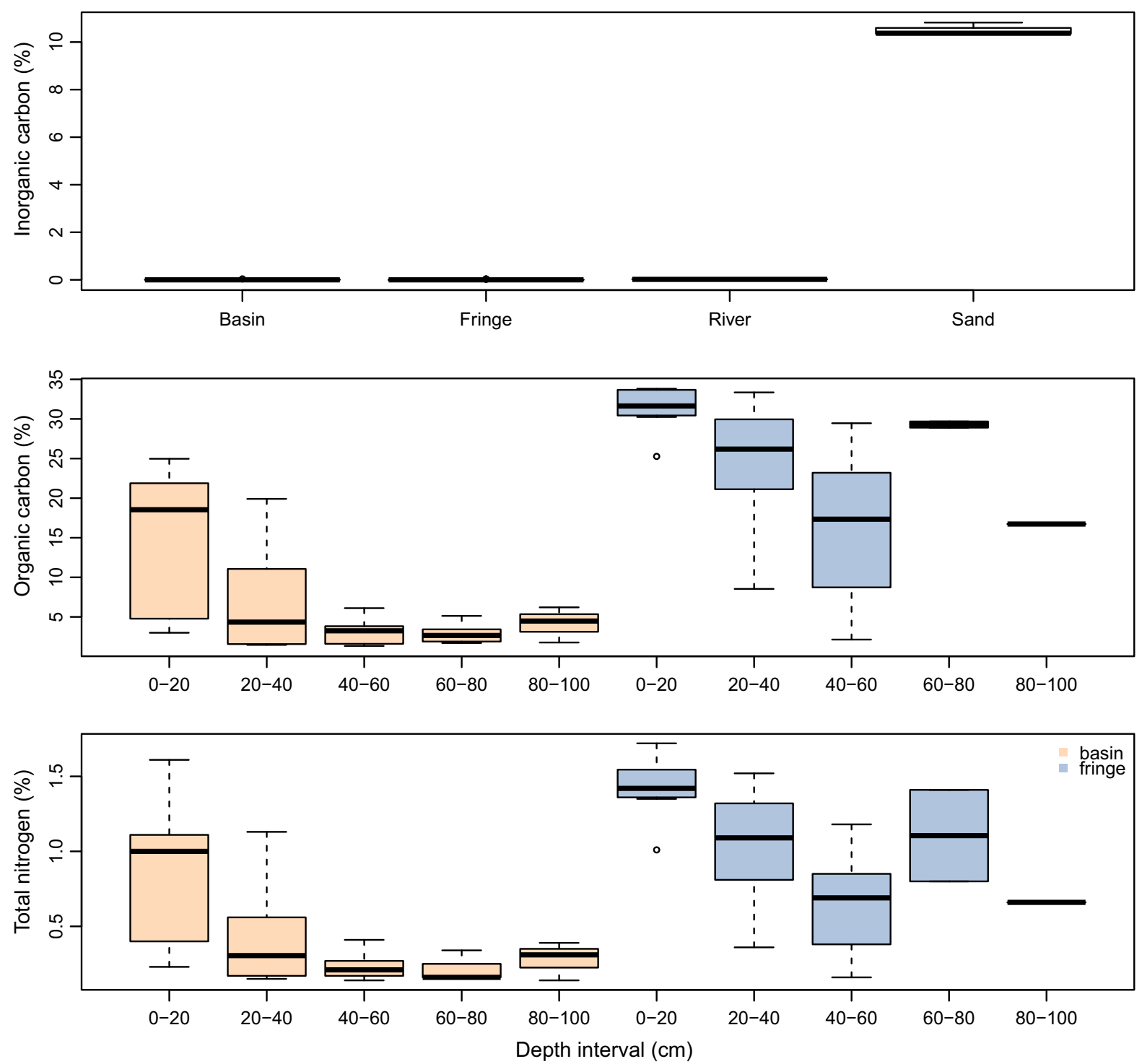

Fig. 2 Observed values of percent inorganic carbon (\% IC) for both mangrove types and end members; and percent organic carbon $(\% \mathrm{OC})$ and percent nitrogen $(\% \mathrm{TN})$ by sampling depth aggregated across plots

$\% \mathrm{TN}$ decreased with soil depth and were highly correlated among each other ( $96 \%$ correlation).

Both end-members, sampled at the Sinú river in Montería and at Nisperal beach, show \%OC and \%TN concentrations close to zero, which indicates that they include almost no organic matter. In contrast, sand plots displayed the highest \% IC concentration of around $10 \%$ (Fig. 2). The lack of organic carbon in the fluvial sediments is evidence against our initial hypothesis of carbon imports to the mangrove system through sedimentation.
We obtained much higher bulk densities for basin than for fringe mangrove soil samples. Average \pm standard deviation of bulk density for fringe mangrove soils was $0.15 \pm 0.02 \mathrm{~g} \mathrm{~cm}^{-3}$, while for basin mangrove soils it was $1.07 \pm 0.12 \mathrm{~g} \mathrm{~cm}^{-3}$ (Table 1). These values confirm previous results on the same area obtained by Bolívar (2015).

The different bulk densities between the two forest types, multiplied by their respective \% organic carbon, resulted in a completely different distribution of TOC compared to the previous results based on \%OC alone 
Table 1 Percent organic carbon, bulk density and total organic carbon by mangrove type and soil depth

\begin{tabular}{lcclc}
\hline Mangrove type & Depth $(\mathrm{cm})$ & OC $(\%)$ & Bulk density $\left(\mathrm{g} \mathrm{cm}^{-3}\right)$ & TOC $\left(\mathrm{MgC} \mathrm{ha}^{-1}\right)$ \\
\hline Basin & $0-20$ & $14.63(10.09)$ & $1.01(0.06)$ & $295.61(203.77)$ \\
& $20-40$ & $7.12(7.19)$ & $1.25(0.10)$ & $161.99(147.07)$ \\
& $40-60$ & $3.22(1.93)$ & $1.06(0.19)$ & $68.35(40.95)$ \\
& $60-80$ & $2.96(1.39)$ & $1.10(0.16)$ & $65.21(30.58)$ \\
Fringe & $80-100$ & $4.15(2.24)$ & $0.84(0.08)$ & $69.78(37.60)$ \\
& $0-20$ & $31.32(2.82)$ & $0.16(0.01)$ & $100.24(9.03)$ \\
& $20-40$ & $23.61(8.70)$ & $0.13(0.02)$ & $62.79(22.56)$ \\
& $40-60$ & $16.12(10.92)$ & $0.16(0.05)$ & $51.57(34.94)$ \\
& $60-80$ & $29.29(0.55)$ & $0.18(0.01)$ & $105.44(1.99)$ \\
\hline
\end{tabular}

(Table 1). A higher carbon storage in the upper layers of basin mangrove soils is clearly outlined (Table 1). Summed across the profile, fringe mangroves had a TOC of $320.04 \pm 42.61 \mathrm{Mg} \mathrm{C} \mathrm{ha}^{-1}$, and basing mangroves an average TOC of $660.93 \pm 259.18 \mathrm{Mg} \mathrm{C}$ $\mathrm{ha}^{-1}$; i.e., average TOC was twice as large in basin than in fringe mangroves. Across the profile, TOC decreased with soil depth within the first four (basin) and three (fringe) layers. There was an increase in TOC for the last measured depth intervals of basin and fringe soils, which can be traced back to higher \%OC values of those layers.

We measured a higher proportion of negative $\delta^{13} \mathrm{C}$ values for fringe soils ( -28 to $-29 \%$ ) than for basin mangroves soils (-25 to $-29 \%$ ) (Fig. 3). Depth intervals $20-40$ and $40-60 \mathrm{~cm}$ of basin soils show outliers with equal ${ }^{13} \mathrm{C}$ values compared to the Sinú river end-member samples with values of around -25 $\%$. The sand end-member samples have the most positive ${ }^{13} \mathrm{C}$ values with approximately $-3 \%$. Strong variations in ${ }^{13} \mathrm{C}$ are conspicuous for the depth intervals $20-40$ and $40-60 \mathrm{~cm}$ of basin mangrove boxplots. We found no identifiable continuous trend between ${ }^{13} \mathrm{C}$ values and depth. However, differences in ${ }^{13} \mathrm{C}$ mean values between fringe and basin mangroves suggest two different distributions ( $p$-value $<$ $0.001, W=542$ ).

There were no differences between basin and fringe mangroves in terms of the composition of their mineral fraction (Table 2). The proportion of mineral soil is larger in basin than in fringe mangroves. Fringe mangrove soils show in contrast a higher proportion of halite than basin soils.

The XRD pattern of sand samples measured from 5 to $60^{\circ} 2 \theta$ provided characteristic ${ }^{\circ} 2 \theta$ intensities for the phases aragonite, calcite and quartz. The XRD measurement combined with a Rietveld refinement yielded a mineralogical composition of $95 \%$ aragonite, $4 \%$ calcite and $1 \%$ quartz. River samples showed high intensities for quartz and sodium feldspar (albite) components, as well as peaks for the clay minerals illite and clinochlore. The semi-quantitative distribution calculated by PDF data indicated that quartz is the main representative of the mineral fraction of the Sinú river soils (Fig. 4).

XRD patterns for both mangrove soils, but in particular for basin soils, showed a similar mineralogical distribution compared to the Sinú river sediments (Fig. 5). XRD patterns in fringe soils showed high intensities for halite, which was also found in basin mangrove soils, but not in a comparable distribution ratio. XRD measurements conducted on the extracted clay mineral fraction yielded peaks for the mineral phases clinochlore, illite, quartz and albite. PDF data additionally identified corundum, which is related to the ceramic panel surface composition. We found major proportions for clinochlore and quartz in the clay size fraction.

The oxalate extraction dissolved much of the poorly crystalline $\mathrm{Fe}$ and $\mathrm{Al}$ oxides from the amorphous materials, whereas the dithionite extraction dissolved the crystalline $\mathrm{Fe}$ oxides as well as the amorphous materials (Fig. 6). Oxalate- and dithionite extracted $\mathrm{Al}$ showed significant differences among fringe and mangrove forest soils ( $p$-value $=0.002, W=325$ ). Similarly, oxalate and dithionite extracted Fe showed significant differences between both soils ( $p$ value $<$ $0.001, W=364)$. Basin soil samples had two times higher concentrations of $\mathrm{Al}\left(\mathrm{Al}_{d}+\mathrm{Al}_{o}\right)$ than fringe soils, and five times higher Fe values. While riverine samples had similar $\mathrm{Al}$ and $\mathrm{Fe}$ concentrations than those of basin mangroves in all 4 extraction patterns, 

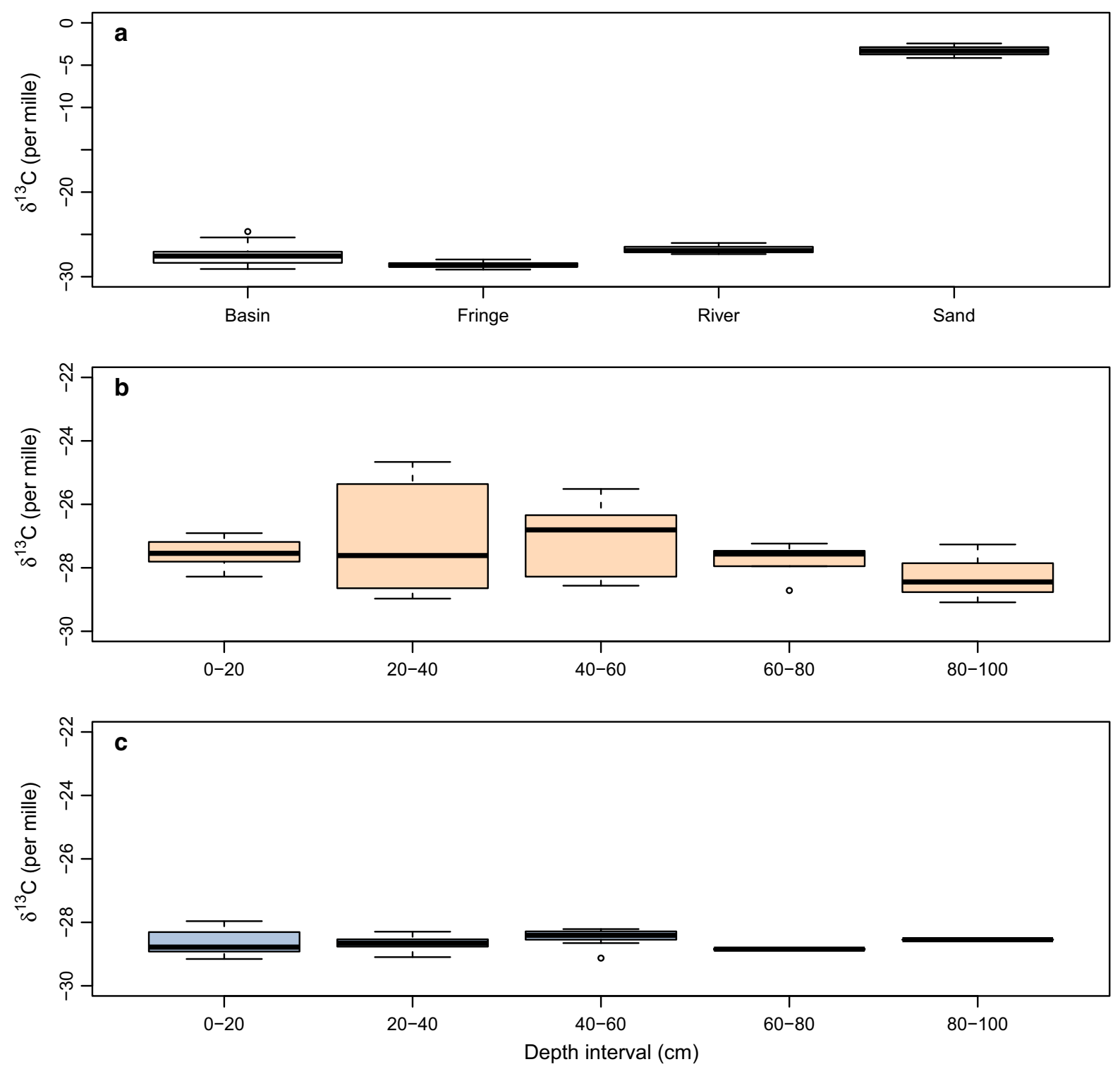

Fig. 3 Measured $\delta^{13} \mathrm{C}$ in a mangrove types and end members, $\mathbf{b}$ basin mangroves by depth, and $\mathbf{c}$ fringe mangroves by depth

Table 2 General mineralogical composition of sediments in Cispatá Bay as measured by XRD analyses

\begin{tabular}{lll}
\hline Class & Mineral & Formula \\
\hline Silicates & Clinochlore & $\left(\mathrm{Mg}, \mathrm{Fe}^{2+}\right)_{5} \mathrm{Al}\left(\mathrm{S}_{\mathrm{i} 3} \mathrm{Al}\right) \mathrm{O}_{10}(\mathrm{OH})_{8}$ \\
& Illite & $\left(\mathrm{K}_{3} \mathrm{H}_{3} \mathrm{O}\right) \mathrm{A}_{12}\left(\mathrm{Si}_{3} \mathrm{Al}\right) \mathrm{O}_{10}\left(\mathrm{H}_{2} \mathrm{O}, \mathrm{OH}\right)_{2}$ \\
& Albite & $\mathrm{NaAlSi}_{3} \mathrm{O}_{8}$ \\
Oxides/hydrox. & Quartz & $\mathrm{SiO}_{2}$ \\
Carbonates & Aragonite & $\mathrm{CaCO}_{3}$ \\
& Calcite & $\mathrm{CaCO}_{3}$ \\
Halides & Halite & $\mathrm{NaCl}$ \\
\hline
\end{tabular}


Sand Nispeyal/ Sample 3

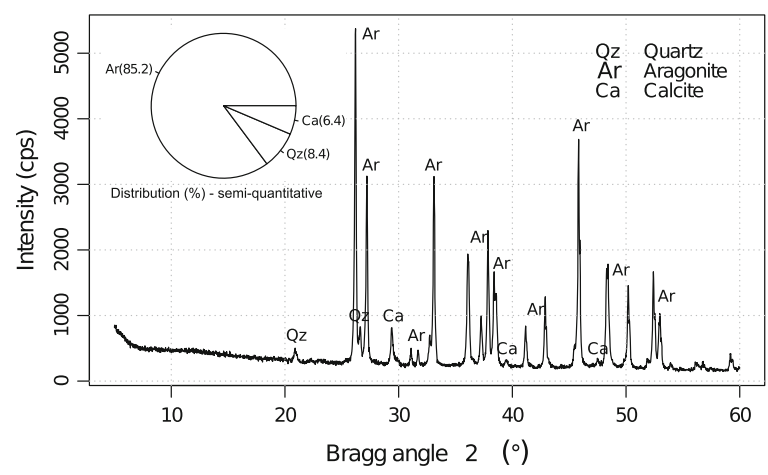

Sinú River/ Sample 3

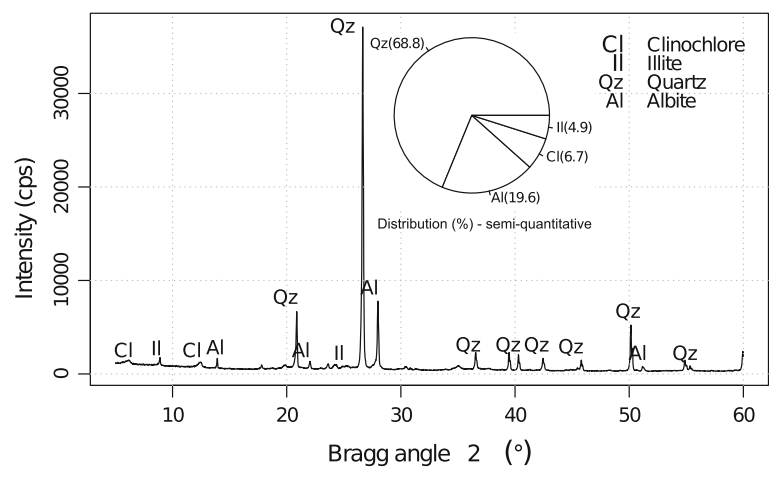

Fig. 4 Two exemplary XRD patterns $(\lambda=1.5406 \AA$ $)$ of both measured end-members: Nisperal beach and Sinú river; figures also include semi-quantitative distribution of detected minerals
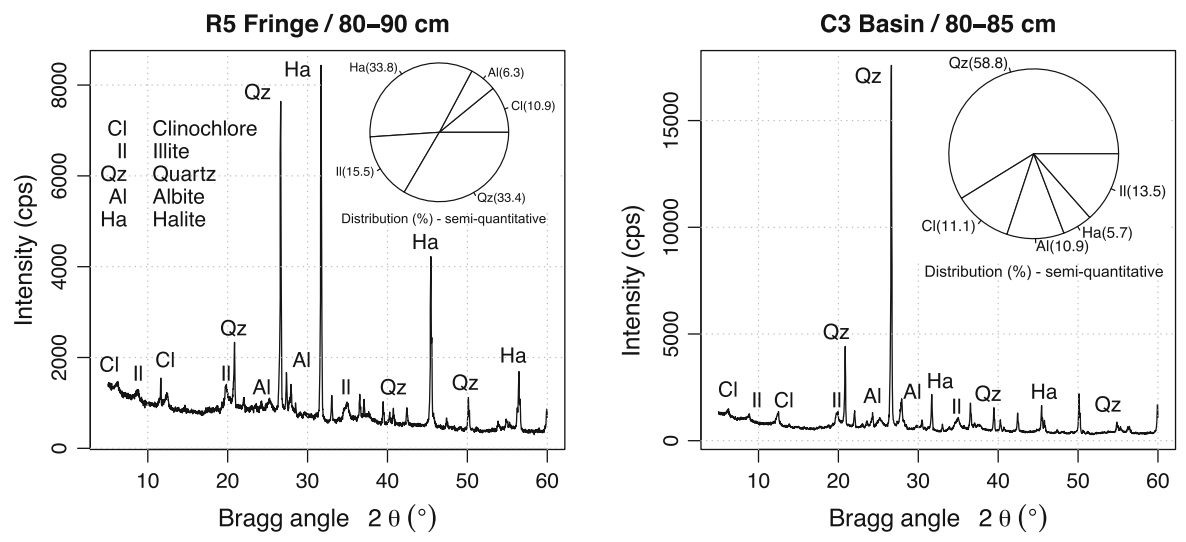

Fig. 5 Two exemplary XRD patterns $(\lambda=1.5406 \AA$ ) for the fringe (left) and basin (right) mangrove soils; figures also include semiquantitative distribution of detected minerals

metal contents of sand samples were constantly low. $\mathrm{Fe}_{d}$ contents differed extremely for basin soils, especially for the first 2 depth intervals. Both basin and fringe soils showed an increase of metal oxides within the first depth intervals and in turn a decrease within the deeper layers.

\section{Discussion}

Our results confirmed previously observed differences in \%OC, bulk density and \% TOC between the basin and the fringe mangrove soils (Bolívar 2015). Furthermore, our measurements of carbon isotopes and mineralogy helped us to explore the potential origin of the carbon stored in both mangrove types. In the following, we will discuss these difference and the potential implications of our findings.

\section{Differences in carbon storage}

Lower values of bulk density in fringe mangrove soils can be explained by their high organic matter content (wood residues, leaf debris and roots). Roots claim a large proportion of the soil volume, which strongly decreases bulk density (Bolívar 2015). Instead, basin mangrove samples of Cispatá bay are characterized by a dense silty composition including a small organic part, which results in higher bulk densities.

The higher proportion of organic matter in fringe than in basin soils also leads to higher \%OC values for fringe soils. Basin mangrove soils instead, are characterized by a small portion of organic topsoil. Because \% TN concentrations correlate with \%OC, 

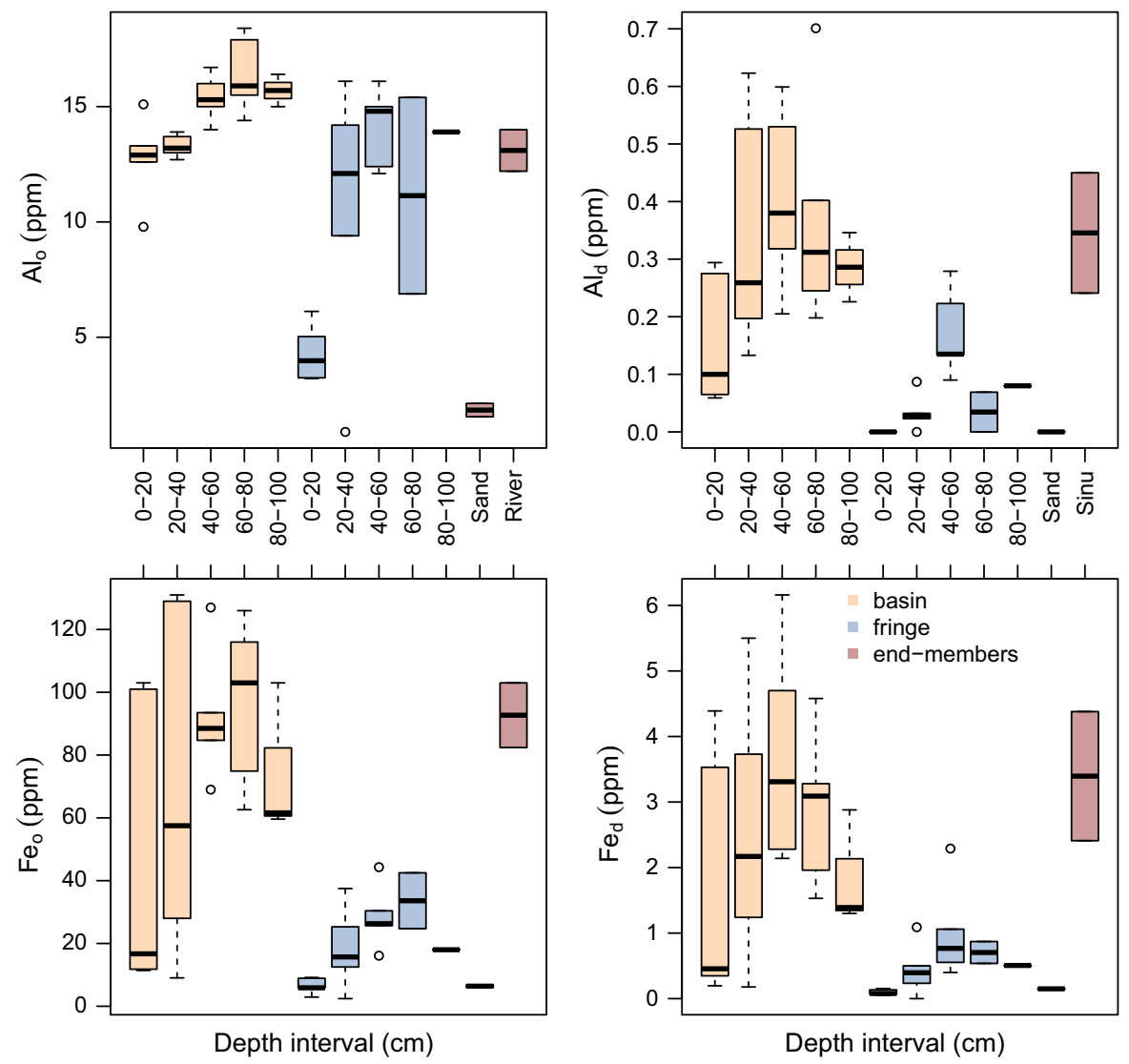

Fig. 6 Oxalate (o)- and dithionite (d) extracted metal oxides for each mangrove type and soil depth

they also show lower values for basin mangroves. That both end-members (river sediments and sand) are mostly consisting of mineral components is illustrated by their \%OC contents of nearly $0 \%$. Because the \% IC concentration of $10 \%$ of sand samples is similar to the used pure calcium carbonate standard, we concluded that the sand end member is mostly composed of carbonates.

The decrease of \%OC with soil depth is likely the result of the interaction between decomposition, vertical transport of organic matter, and leaching of dissolved carbon in water (Elzein and Balesdent 1995; Braakhekke et al. 2013; Mathieu et al. 2015). Because soil microorganisms utilize nitrogen and bacteria fix nitrogen, the concentration of \% TN also decreases with depth. The fact that concentrations of \%OC and $\% \mathrm{TN}$ decrease continuously with soil depth, but still show layers with higher concentrations in depths of 80-100 cm (basin) and 60-80 cm (fringe), may reflect differences in sedimentation rates over time (Bolívar
2015). In Cispatá bay, silting processes linked to changes in the position of the Sinú river delta, current sea level rise, flooding regime and fluvial inputs (Serrano 2004), can generate deep organic layers that may cause the increase of \%OC with depth for both mangrove types.

Higher TOC values in basin mangrove soils reflect higher rates of organic matter accumulation. According to Bolívar (2015), the percentage of clay is similar between both mangrove types. However, the silt fraction dominates in all soil profiles in basin mangroves, while sand dominates in fringe mangrove soils. It has been well established that soil particles with greater surface area, as typical of finer textures like those found in basin mangroves, decrease drainage and decomposition of organic matter (Prasad and Ramanathan 2008). Because TOC contents are linked to \%OC, we found also an increase of TOC in depth levels of $80-100 \mathrm{~cm}$ (basin) and $60-80 \mathrm{~cm}$ (fringe). 
Our results confirm previous studies that found important differences in TOC between fringe and basin mangrove soils (Bolívar 2015). Furthermore, basin mangrove soils showed a significantly higher range of in-situ produced carbon than fringe mangrove soils, and with it a higher carbon storage of $661 \pm 259$ $\mathrm{MgC} \mathrm{ha}{ }^{-1}(0-100 \mathrm{~cm})$ compared to $320 \pm 43 \mathrm{MgC}$ $\mathrm{ha}^{-1}(0-80 \mathrm{~cm})$. Based on the $\%$ IC concentration results, we infer that marine sediments across Cispatá bay have little to no influence on additional carbon entering via tidal flooding, which is supported by the lack of \%IC content in the analyzed mangrove soil samples compared to the sands of Nisperal beach.

\section{Origin of carbon}

$\delta^{13} \mathrm{C}$ values of fringe mangrove sediments were more ${ }^{13} \mathrm{C}$ depleted than basin sediments, which is a strong indication that this carbon is more plant derived. C3 plants fractionate ${ }^{13} \mathrm{C}$ during photosynthesis, with values from -22 to $-38 \%$, while $\mathrm{C} 4$ plants show values between -8 and $-15 \%$ (Farquhar et al. 1989). R. mangle, a typical C3 species, mostly occurs in the fringe area of Cispatá bay (Bolívar 2015) and is therefore the main contributor of ${ }^{13} \mathrm{C}$ in this type of forest. In terms of its origin, this carbon is very likely produced in situ in the area. Basin mangrove sediments instead, show a wider range of $\delta^{13} \mathrm{C}$ values and more positive values. This could mean either that the basin area has a higher contribution by $\mathrm{C} 4$ plants (e.g., grasses), or that there is some contribution from mineral sources. Because the most common basin mangrove species, A. germinans, is also a $\mathrm{C} 3$ plant and there is likely little contribution by $\mathrm{C} 4$ grasses, we assumed that basin mangrove sediments have some influence by deposited sediments from the Sinú river. This assumption is also supported by the fact that basin samples tend to have more enriched $13 \mathrm{C}$ values, close to those found for the Sinú river samples (- $25 \%$ ). According to Ruttenberg and Goni (1997) and Powers and Veldkamp (2005), $\delta^{13} \mathrm{C}$ values of tropical mineral soils range from -23 to $-26 \%$, which would underpin mineral derived ${ }^{13} \mathrm{C}$ values in Cispatá bay. Because differences in ${ }^{13} \mathrm{C}$ values were significant between basin and fringe sediments, and because fringe samples only have plant derived ${ }^{13} \mathrm{C}$, we conclude that the fringe area is not influenced by the Sinú river delta. It also does not show any influence through marine sediments, because it does not have any enriched values comparable to the sand end member $(-5 \%)$.

The $\delta^{13} \mathrm{C}$ analyses confirmed that additional carbon present in basin soils is only terrestrial and not marine derived. Moreover, it shows that additional terrestrial carbon only influences basin mangrove sediments, while carbon in fringe soils is exclusively produced in situ by the plants.

Using XRD, we found that the mineralogical composition of the sediments in Cispatá bay was similar to the composition of the Sinú river sediments in Montería. We therefore conclude that basin and fringe mangrove sediments were transported by the river and have their distant origin in that river basin. Quartz, albite and clay minerals are the major components of those sediments. Additionally, plot R5 shows intense peaks for the mineral halite in depths between 80 and $90 \mathrm{~cm}$. Because halite crystallizes by the evaporation of sea water and intense salinization (McCaffrey et al. 1987), its occurrence verifies that the fringe mangrove area has tidal influence of hyper saline sea water. Furthermore, halite confirms the sediment's air exposition, since it needs evaporation to be formed. That halite reaches that intense proportion in depths of $80-90 \mathrm{~cm}$ can be attributed to the changing course of the Sinú river. According to Serrano (2004), the river course passed through the northern main land of Cispatá bay between 1849 and 1938, where plot R5 is located. Accordingly, the sedimentation rate increased in that period. However, before that period, this region was more influenced by saline sea water, which results in intense halite peaks. That basin soils also contain halite, shows that they were also occasionally flooded.

Along with the ${ }^{13} \mathrm{C}$ results, the mineralogical analyses also confirmed that basin mangrove sediments are terrestrially derived as opposed to marine derived. This finding is also reflected in higher metal oxide and hydroxide contents in basin than in fringe mangrove soils. Concentrations of iron and aluminum oxides in basin mangroves were similar to those of the Sinú river samples, which is a strong indication of fluvial deposition of inland sediments.

That mineral surfaces of $\mathrm{Al}$ and $\mathrm{Fe}$ oxides and hydroxides adsorb dissolved organic matter (DOM) has been well established (Tipping 1981; Oades 1988; Kaiser and Guggenberger 2000; Mikutta et al. 2006). It is therefore very likely that metal oxides and hydroxides bind and preserve $\mathrm{C}$ in basin mangrove 
soils. According to Kaiser and Guggenberger (2000), the capacity to adsorb DOM relates to the presence of $\mathrm{Al}$ and $\mathrm{Fe}$ oxides and hydroxides. The sorption of $\mathrm{DOM}$ derived from decomposition to $\mathrm{Al}$ and $\mathrm{Fe}$ oxyhydroxides involves strong complexation bondings between surface metals and acidic organic ligands, particularly with those associated with aromatic structures. The strength of the sorption relates further to the surface properties of the sorbing mineral phase. Kaiser and Guggenberger (2000) found that dissolved organic matter sorption is strongly enhanced by hydrous oxide coatings and particularly by amorphous $\mathrm{Al}(\mathrm{OH})_{3}$, which may indicate that amorphous hydroxides bind $\mathrm{C}$ in basin soils of Cispatá bay. Tipping (1981) describes moreover, that the extent of adsorption of DOM increases with decreasing $\mathrm{pH}$. Because mangrove soils at the Colombian Caribbean coast have an acid character both at $A$. germinans and R. mangle forests (Urrego et al. 2014), a stronger C binding onto oxides and hydroxides is substantiated in this region.

All together, we found no evidence for our initial hypothesis that $\mathrm{C}$ in mangroves of Cispatá bay, particularly in basin soils, have a large contribution from sediments transported by the Sinú river. Instead, we found that the sediments do play an important role for stabilizing in situ produced carbon, but mostly by providing mineral surfaces for $\mathrm{C}$ binding.

\section{Implications}

Our results provide strong evidence for an important role of sediment mineralogy, particularly iron and aluminum oxides, in providing mineral surfaces for the adsorption of dissolved carbon and long-term $\mathrm{C}$ retention (Oades 1988) in mangrove soils. These results add a new dimension to the more traditional studies of carbon origin in mangrove soils where the source of the carbon is considered either marine or terrestrially derived (Lacerda et al. 1995; Bouillon et al. 2008), without considering the role of sediments in dissolved carbon retention. This mechanism may play a large role in explaining observed spatial variability in carbon storage (Alongi 2012; Jardine and Siikamäki 2014). Also, since retention of dissolved carbon in mangrove soils can reduce rates of carbon exports to the ocean (Adame and Lovelock 2011), mineral surfaces of sediments may provide a large potential for carbon sequestration in mangrove ecosystems located around river deltas. According to our results, carbon storage can be twice as high in mangroves with dense aggregation of minerals than in more organic mangrove soils, and therefore it is very relevant to explore this carbon sequestration mechanism in other delta regions of the world.

\section{Conclusions}

Based on analyses of carbon concentration, stable isotopes of carbon, and mineralogy, we found that most carbon stored in soils of Cispatá Bay, Colombia, is produced in situ, with little evidence of carbon imported to the area either by fluvial or marine sedimentation. Interior basin mangroves store significantly more carbon in soils than the more ocean exposed fringe mangroves. Sediments transported by the Sinú river and deposited in the delta region contain negligible amounts of organic carbon, but the mineralogical composition of these sediments favors the adsorption of dissolved carbon on charged mineral surfaces, which explains the larger levels of $\mathrm{C}$ storage in this type of mangroves.

Our study highlights the importance of fluvial sediment transport in providing a substrate for carbon stabilization through mineral protection. This mechanism for soil carbon storage has been little studied previously in mangrove ecosystems, but it has large implications for determining their potential for longterm carbon sequestration.

Acknowledgements Open access funding provided by Max Planck Society. We would like to thank Prof. Dr. Juraj Majzlan for providing mentoring and access to the XRD lab at the Friedrich-Schiller-Universität Jena. Thanks to INVEMAR Colombia, particularly Paula C. Sierra, for facilitating logistics and access to the research site. Financial support was provided by the Alexander von Humboldt Foundation through the International Climate Protection Fellowship (KOL 1157857 IKS-2), and the Max Planck Institute for Biogeochemistry.

Open Access This article is distributed under the terms of the Creative Commons Attribution 4.0 International License (http:// creativecommons.org/licenses/by/4.0/), which permits unrestricted use, distribution, and reproduction in any medium, provided you give appropriate credit to the original author(s) and the source, provide a link to the Creative Commons license, and indicate if changes were made. 


\section{References}

Adame MF, Lovelock CE (2011) Carbon and nutrient exchange of mangrove forests with the coastal ocean. Hydrobiologia 663(1):23-50. https://doi.org/10.1007/s10750-010-0554-7

Alongi DM (2012) Carbon sequestration in mangrove forests. Carbon Manag 3(3):313-322

Bolívar J (2015) Soil and root carbon in two types of mangroves in Cispatá bay (Colombian Caribbean). Master's thesis, Universidad Nacional de Colombia sede Medellín

Bouillon S, Connolly R, Lee S (2008) Organic matter exchange and cycling in mangrove ecosystems: recent insights from stable isotope studies. J Sea Res 59(1):44-58 (Macrobenthos Special Issue)

Braakhekke MC, Wutzler T, Beer C, Kattge J, Schrumpf M, Ahrens B, Schöning I, Hoosbeek MR, Kruijt B, Kabat P, Reichstein M (2013) Modeling the vertical soil organic matter profile using bayesian parameter estimation. Biogeosciences 10(1):399-420. https://doi.org/10.5194/bg10-399-2013

Donato DC, Kauffman JB, Murdiyarso D, Kurnianto S, Stidham M, Kanninen M (2011) Mangroves among the most carbon-rich forests in the tropics. Nat Geosci 4(5):293-297. https://doi.org/10.1038/ngeo1123

Elzein A, Balesdent J (1995) Mechanistic simulation of vertical distribution of carbon concentrations and residence times in soils. Soil Sci Soc Am J 59(5):1328-1335

Farquhar GD, Ehleringer JR, Hubick KT (1989) Carbon isotope discrimination and photosynthesis. Annu Rev Plant Physiol Plant Mol Biol 40(1):503-537. https://doi.org/10.1146/ annurev.pp.40.060189.002443

Fry B (2006) Stable isotope ecology. Springer, New York. https://doi.org/10.1007/0-387-33745-8_1

Hollander M, Wolfe DA, Chicken E (2015) Nonparametric statistical methods. Wiley-Blackwell, Hoboken. https:// doi.org/10.1002/9781119196037.fmatter

Holmgren GGS (1967) A rapid citrate-dithionite extractable iron procedure. Soil Sci Soc Am J 31(2):210-211. https://doi.org/10.2136/sssaj1967. 03615995003100020020x

Jardine SL, Siikamäki JV (2014) A global predictive model of carbon in mangrove soils. Environ Res Lett 9(10):104013

Kaiser K, Guggenberger G (2000) The role of DOM sorption to mineral surfaces in the preservation of organic matter in soils. Org Geochem 31(7):711-725

Lacerda L, Ittekkot V, Patchineelam S (1995) Biogeochemistry of mangrove soil organic matter: a comparison between rhizophora and avicennia soils in south-eastern Brazil. Estuar Coast Shelf Sci 40(6):713-720

Mathieu JA, Hatté C, Balesdent J, Parent É (2015) Deep soil carbon dynamics are driven more by soil type than by climate: a worldwide meta-analysis of radiocarbon profiles. Glob Chang Biol 21(11):4278-4292. https://doi.org/ 10.1111/gcb.13012

McCaffrey MA, Lazar B, Holland HD (1987) The evaporation path of seawater and the coprecipitation of br (super-) and k (super +) with halite. J Sediment Res 57(5):928-937. https://doi.org/10.1306/212F8CAB-2B24-11D7-8648000 102C1865D

Mikutta R, Kleber M, Torn MS, Jahn R (2006) Stabilization of soil organic matter: association with minerals or chemical recalcitrance? Biogeochemistry 77(1):25-56. https://doi. org/10.1007/s10533-005-0712-6

Oades JM (1988) The retention of organic matter in soils. Biogeochemistry 5(1):35-70. https://doi.org/10.1007/ BF02180317

Powers JS, Veldkamp E (2005) Regional variation in soil carbon and $\delta^{13} \mathrm{C}$ in forests and pastures of northeastern Costa Rica. Biogeochemistry 72(3):315-336

Prasad MBK, Ramanathan A (2008) Sedimentary nutrient dynamics in a tropical estuarine mangrove ecosystem. Estuar Coast Shelf Sci 80(1):60-66

Ruttenberg K, Goni M (1997) Phosphorus distribution, C:N:P ratios, and $\delta^{13} 13 \mathrm{C}$ oc in arctic, temperate, and tropical coastal sediments: tools for characterizing bulk sedimentary organic matter. Mar Geol 139(1):123-145

Schwertmann U (1964) Differenzierung der eisenoxide des bodens durch extraktion mit ammoniumoxalat-lösung. Z Pflanzenernähr Düng Bodenkd 105(3):194-202. https:// doi.org/10.1002/jpln.3591050303

Serrano BE (2004) The Sinú river delta on the northwestern Caribbean coast of Colombia: bay infilling associated with delta development. J South Am Earth Sci 16(7):623-631

Spieß L, Teichert G, Schwarzer R, Behnken H, Genzel C (2009) Moderne röntgenbeugung: röntgendiffraktometrie für materialwissenschaftler. Physiker und chemiker. Springer, New York

Spohn M, Giani L (2012) Carbohydrates, carbon and nitrogen in soils of a marine and a brackish marsh as influenced by inundation frequency. Estuar Coast Shelf Sci 107:89-96

Spohn M, Babka B, Giani L (2013) Changes in soil organic matter quality during sea-influenced marsh soil development at the North Sea coast. Catena 107:110-117

Tipping E (1981) The adsorption of aquatic humic substances by iron oxides. Geochim Cosmochim Acta 45(2):191-199

Urrego L, Molina E, Suárez J (2014) Environmental and anthropogenic influences on the distribution, structure, and floristic composition of mangrove forests of the Gulf of Urabá (Colombian Caribbean). Aquat Bot 114:42-49

Werner RA, Brand WA (2001) Referencing strategies and techniques in stable isotope ratio analysis. Rapid Commun Mass Spectromet 15(7):501-519 